\title{
Applying Contract Farming Modelin Welfare-Enhancing Effort for Palm Oil Farmers in Sanggau Regency (West Kalimantan)
}

\author{
Jamaliah $^{1}$ \\ ${ }^{1}$ Fakultas Ekonomi dan Bisnis, Universitas Tanjungpura, Pontianak, Indonesia \\ Correspondence: Jamaliah, Fakultas Ekonomi dan Bisnis, Universitas Tanjungpura, Pontianak, West Kalimantan, \\ Indonesia.
}

Received: March3, 2018

Accepted: March 23, 2018

Online Published: March 26, 2018

doi:10.20849/ajsss.v3i1.352

URL: https://doi.org/10.20849/ajsss.v3i1.352

\begin{abstract}
The main problem in this research is to find out how contract farming (CF) model can be implemented and optimized in the welfare-enhancing efforts for the palm oil farmers in Meliau District, Sanggau Regency. This research aims to generate an insight of social, economy, and demography condition of the palm oil farmers, as well as determining the contract farming model as a welfare-enhancing effort. This research employs qualitative method based on the information from the parties involved, such as farmers, businessmen, government, and notable figures among society. The data are analyzed using interpretation method so that the information meaning can be understood and further strengthen the analysis and conclusion. This study's findings are: 1) the population growth is caused by the increasing number of migration and the labor force (which is encompassed 56.37 percent of total population) mostly works as palm oil farmers; 2) contract farming model is very likely to be conducted through agreement, understanding, and similarity of vision in production, input management, technology, product quantity and quality, price, and marketing; and 3) the provincial and regional governments roles (also notable figures', NGO's, and universities' roles) are immensely great in supporting and monitoring the CF model.
\end{abstract}

Keyword: contract farming, welfare-enhancing, palm oil farmers

\section{Introduction}

\subsection{Research Background}

"Independent, Impartial, and Prosperous Indonesia" is the long-term development vision for Indonesia in 2005-2025. The government is always advocating independence, improvement, justice, and prosperity to attain welfare for every citizen of Indonesia.

Welfare is important for every citizen, as stated by Soekarno (in Husodo 2007:21). He defined welfare as a real-life condition strived by many entities, including a nation, so that all citizens can live prosperously. This condition can be achieved attributable to the independent, productive, and efficient economy system so that individuals can save their earnings.

Observing the importance of agriculture sector for a country, Kusreni (2009:9) stated that developing the agriculture sector to maintain food security is indisputable, as this country shall be sovereign in providing its people food. While Basri (2014:9) affirms that the trade balance deficit in the last few years of President SBY administration is caused by unfavorable government policy toward agriculture sector. It is proven by the proportion of National Budget (APBN) in which agriculture sector subsidy (for fertilizers and seeds procurement) was taken up only 4 percent of the total budget; while fuel subsidy acquired 57 percent of overall budget.

Meanwhile, the role of Sanggau Regency in the development of palm oil can be traced back to 1978 until today. Sanggau Regency itself is recorded as the largest Crude Palm Oil (CPO) and Palm Kernel Oil (PKO) producer among all regencies in West Kalimantan Province. However, this success is not in line with the improvement of people welfare in the region, because Sanggau Regency has always been in either $5^{\text {th }}$ or $6^{\text {th }}$ welfare ranking out of 14 regencies in West Kalimantan Province. Moreover, in 2013, based on the BPS (National Statistic Board) data, Sanggau Regency still has 10,884 household (KK) living in poverty; ranging from the Prosperous Family Group I(3,009 households) to Prosperous Family Group II (vulnerable to poverty) with 7,836 households. 
One of the efforts to improve the welfare of palm oil farmers is contract farming (CF) model. Contract Farming (CF) or memorandum of agreement is basically a general agreement composed by the parties involved to protect their common interests, to conduct all clauses consistently, and not to violate any agreed consensus. CF is commonly found in some areas in Indonesia where agriculture remains the main sector of its economy.

Singh (2000) stated that "contract farming as a system would affect the producers positively or negatively depends on the context of the economy". After observing various CF practices, especially among farmers and corporations in India, Singh concluded that not all CF contributed positively to the famers' lives and welfare, some even affected them negatively.

Asokan (2003) firmly expressed that "this system can be traced back to the colonial period when the cotton and indigo were produced by the Indian farmers for the English factories". Asokan worried that the contract farming model in India shall bring back feudal relationship which occurred in India during colonialism era, especially between cotton farmers and British colonial companies.

Contract farming, which is commonly occurred between farmers and big corporations, offers both negative and positive impact. This social phenomenon happens in both Sanggau Regency and West Kalimantan Province. Therefore, it is considered necessary to conduct a research in the palm oil investment and development area, especially about CF. It is also necessary to design CF development model so that no parties (either farmers, corporates, investors, or government) suffer from loss and in turn, CF could improve farmers' welfare.

\subsection{Research Question}

Based on the research background above, the research question is formulated: how contract farming (CF) model can be developed and optimalized to improve palm oil farmers' welfare in Meliau District, Sanggau Regency.

\subsection{Research Objectives}

1. To provide an insight on social, economy, and demography conditions of palm oil farmers in Sanggau Regency.

2. To determine the contract farming development model in welfare-enhancing efforts for palm oil farmers in Sanggau Regency.

\section{Literature Review}

\subsection{Theoretical Framework}

\subsubsection{Contract Farming}

Prowse (2012) stated that " $\mathrm{CF}$ is a form of vertical integration within agricultural commodity chains, to the extent that the firm has greater control over the production process, the quantity, quality, characteristics, and the timing of what is produced."

According to Bijmen (2008) "CF has been defined as an agreement between one or more farmer(s) and a contractorfor the production and supply of agricultural product under forward agreement, frequently at pre-determined price. "While the US Departement of Agriculture defines contract farming as" the growing and marketing of farm products under such circumstances that selective terms of the grower and the processor or shipper before production is undertaken".

Meanwhile, Singh (2000) emphasized on the positive and negative sides of CF signed by the farmers and companies, particularly for the farmers. Roy (in Singh. 2000) argued that CF is just a common contract between farmers and companies which is specifically composed for the production and marketing of farming products. $\mathrm{CF}$, which is composed by the farmers and companies, actually aims to encourage both parties to retain the common trust and commitments in fulfilling each contract clause; particularly in terms of quantity, quality, punctuality, and purchase (Nagaraj et al. 2008).

The arguments by Nagaraj et al. (2008) were strengthened by Eaton, Andrew, W, and Kismantotoadji (in Erfit, 2011). They stated that contract farming is a cooperation between farmers with corporations (either state-owned or private) which is tied by a contract containing terms and conditions. The terms and conditions consist of price, production, processing, marketing, and commodities. The contract also includes input procurement, product quantity, and product quality. CF is expected to increase farmers' income, as well as technology usage and farmers' productivity. 


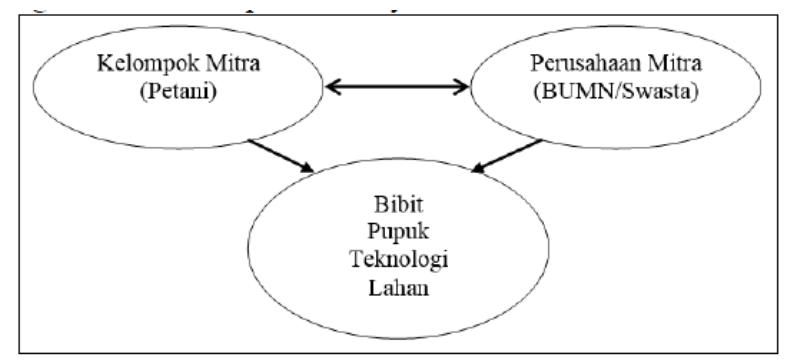

Source: Erfit (2011)

Figure 1. The partnership form between farmers and corporate partners in contract farming

With regards to CF, a relatively moderate view is stated by Sussane (2014), "the term 'contract farming' comprised institutional arrangements which formalize a farmers' supply of a contracted commodity to a processing or retailing company". Although Sussane's definition on the terminology is similar with others, but $\mathrm{CF}$ in practice is not as simple as its definition. The influence of CF in daily life is tangible and directly affects both farmers and other parties involved in it. Therefore, CF cannot be considered as a mere formalization of an agreement between corporations and farmers, because it also contains some consequences on the farmers as the price takers. It is acknowledged that CF brings about positive impacts toward the farmers, but it also contains some negative ones, such as the farmers' weakening bargaining positions.

\subsubsection{Welfare Theory}

Welfare is one's individualistic perception with regards to the value of life satisfaction and physical satisfaction. Greve (2008) explained that welfare is derived from 'wel' and 'fare'. Spencer (in Greve, 2008) stated that welfare is related to well-beingness. While according to Oxford Dictionary (in Greve, 2008), welfare's definitions consist of: 1) well-being, happiness, health, and prosperity (of person, community, etc.); and 2) [welfare] is related to financial support from the state.

Suman (2009:1) asserts that welfare is related to a concept about interaction; namely a connected relationship between one person with others. There's a possibility that one party reduces the welfare of another party in such interaction. Based on such thought, welfare is clearly the reality of social-economy life as a result of a long-term relationship pattern. The relationship is built either between one personnel or between institutions which is aimed to gain value to improve income and welfare. As a concept, "welfare" is simply a social-economy life of someone who is economically prosperous and socially capable.Furthermore, a country is considered as a welfare state if it fulfills the four pillars: social citizenship; full democracy; modern industrial relation systems and rights to education; and the expansion of modern mass education systems. Those economy, social, and politics requirements are the reasons why not all densely populated and high income countries can be considered as welfare states.

Meanwhile, welfare is tightly related to individual perception and income utility, thus, it is difficult to measure. Welfare measurement in macro level uses Gross Domestics Products per capita as a proxy and it is acknowledged as a good indicator. Greve (2008) explained that welfare concept shall be understood in deeper historical and cultural contexts, because it can influence the understanding about the long-standing history on the welfare concept itself.

\section{Research Methodology}

\subsection{Research Design}

With quantitative and qualitative methods, based on its character, this research is included in descriptive research. Descriptive research aims to illustrate the object's characteristics (Ruslan, 2006:12). This research shall be equipped with a research chart to illustrate its stages, starting from the research location, framework, analyses' results, and results' indicators.

\subsection{Primary and Secondary Data Source}

The primary data are obtained from interviews with palm oil farmers, corporations, and government. They are expected to know about palm oil investment activities in Meliau District. The notable figures (informal and formal) in Meliau District are also being interviewed to enrich the interview analyses. While the secondary data is obtained from documents related to the research, literature study, and government institution (BPS, 2014). 


\subsection{Data Collection Method}

This study uses several data collection techniques from informants, which are conducted separately in accordance with the informant groups. Basrowi (2008:188), Ahmadi (2014:93) stated that informants in a qualitative research hold a core role and special knowledge, because a qualitative research emphasizes on the information depth and meaning.

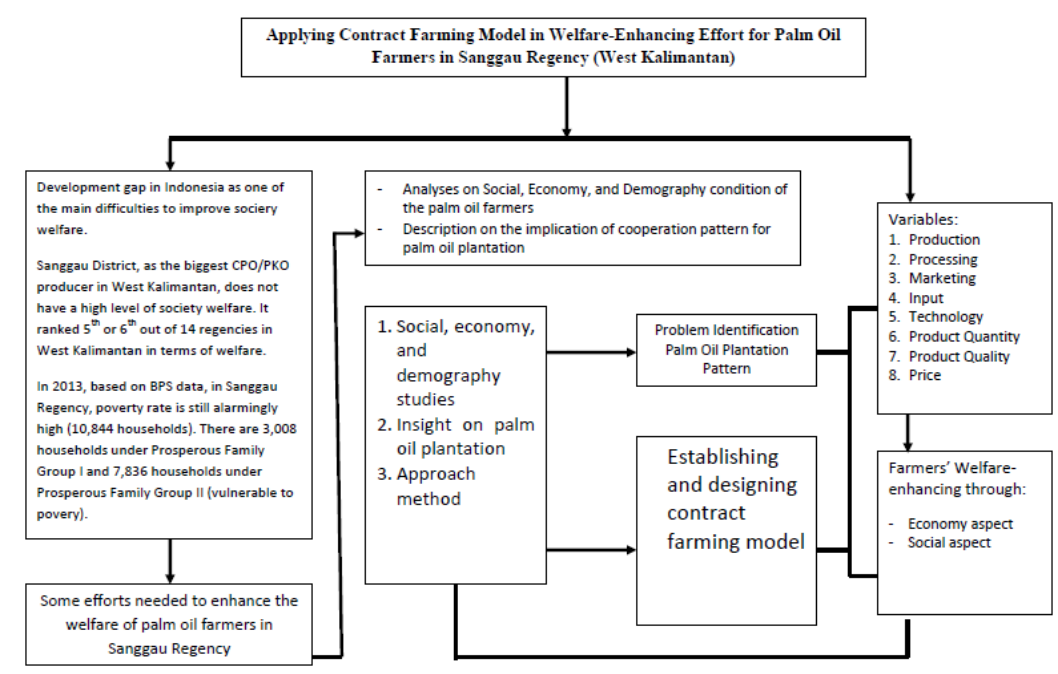

Figure 2. Research framework

\subsubsection{In-Depth Interview}

In-depth interview method is used to obtain direct and deep data and information from research subjects. Key informants in this interview have direct relations in palm farming activity and are involved in contract farming, namely farmers, entrepreneurs, and village officials.

\subsubsection{Observation}

Observation is a data collecting method which is used by systematically observing and noting phenomena that is being examined. Observation in this research is the impact of CF to farmers' welfare.

\subsection{Population and Sample}

Population in this study is the sum of all farmers, palm oil companies, and village officials. Samples are selected purposively — in line with research objective — who are consist of 3 farmers, 1 company, and 1 village official.

\subsection{Variable Definition}

CF development is a cooperation agreement, not only on price and profit sharing, but also on improvement of production, process, marketing, technology, and product quantity and quality. Meanwhile, farmers' welfare is the socio-economical condition of the farmers which is measured through the net income of palm farming.

\subsection{Data Analysis}

Sugiyono (2011:333) assessed that data analysis in qualitative research is conducted prior to the field research, during the research, and the aftermath. Data analysis is the reference for future research and, if possible, acts as a grounded theory. In this research, data analyses are conducted quantitatively and qualitatively. The data obtained from quantitative (tabulation of data with frequency tables) for subsequent inter predation interpretative data; thus, the contained meaning in the information can be understood and utilized to strengthen the analysis and draw the conclusion.

\section{Discussion}

Meliau District is one the first investment destinations in West Kalimantan since 1980. Every year, due to migration, its population keeps increasing. There are 24,255 male populations and 21,895 female populations in 2012 (BPS, 2013). As it occupies $1,495.7 \mathrm{~km}^{2}$ area with total number of population 46,150 people, its average 
population density is 30.86 people per $\mathrm{km}^{2}$. It is slightly below the average population density in Sanggau Regency (31.77 people per $\mathrm{km}^{2}$ ).

As one of the investment destinations, Meliau District attracts migration. As a result, in four decades, this district has developed as the second most densely populated district in Sanggu Regency with 46,150 people. Based on BPS (2013) data, the number of labor force in the district is recorded at 26,014 people which is 56.37 percent of the total population. This number is relatively higher than the average number of labor force in Sanggau Regency which is recorded at 50.90 percent.

A significantly high population growth in Meliau District proves that this area appeals to many parties, particularly for business or investment. Currently, numerous large sized-palm oil companies (both large state plantation $\langle\mathrm{PBN}\rangle$ and private plantation $\langle\mathrm{PBS}\rangle$ ) were established and occupied most of the Other Usage Area (APL) for palmoil plantation.

However, ironically, based on the interviews with some informants (village officials), there are 14 out of 19 villages (73.68\%) in Meliau Districts vulnerably living in poverty. Specifically, there are 3,008 households in Prosperous Family Group I and 7,836 households in Prosperous Family Group II. The total number is 10,844 people or 23.50 percent of the total population in Meliau District.

Table1. Palm oil plantation corporation - PBN/PBS at Meliau district 2014

\begin{tabular}{llll}
\hline No & Regency/Corporation & Location & Commodity \\
\hline PBN & & & \\
\hline 1 & BUMN PTPN-13 & Meliau, Tayan Hilir & Palm Oil \\
\hline PBS & & & \\
\hline 1 & PT. Bintang Harapan Desa & Meliau & Palm Oil \\
2 & PT. Sawit Desa Kapuas & Meliau, Tayan Hilir, Toba & Palm Oil \\
3 & PT. Sumatra Jaya Agro Leastari & Meliau, Toba & Palm Oil \\
4 & PT. Surya Borneo Indah & Meliau, Tayan Hilir & Palm Oil \\
5 & PT. Agro Abadi Cemerlang & Meliau, Toba & Palm Oil \\
6 & PT. Borneo Edo Internt. Agro & Meliau, Tayan Hilir, Toba & Palm Oil \\
\hline
\end{tabular}

Source: Plantation Agency of West Kalimantan Province, 2014

\subsection{Palm Oil Investment Cooperation with Corporations}

There are three investment patterns conducted by PBN/PBS in Meliau District, starting from the beginning of palm oil plantation at this district until this research is conducted. Those three patterns are PIR-Trans, PIR-Bun, and KKPA. They are officially regulated by the government under the Department of Agriculture, Republic of Indonesia. Meanwhile, there is another pattern which is independently developed by the locals, namely People Plantation Pattern (PR). This pattern has been a partnership pattern between PBN/PBS with the locals to establish a mutual cooperation.

An investment is expected to give some value added to the society. However, it will not be able to improve the farmers' welfare if the value is disproportionately distributed based on the extent of society's sacrifice and involvement. Figure 4 displays the comparison of the value added received by each party, starting from palm oil cultivation and harvest time until it is sold to the Palm Oil Monitoring System (PMS) in PBS/PBN. 


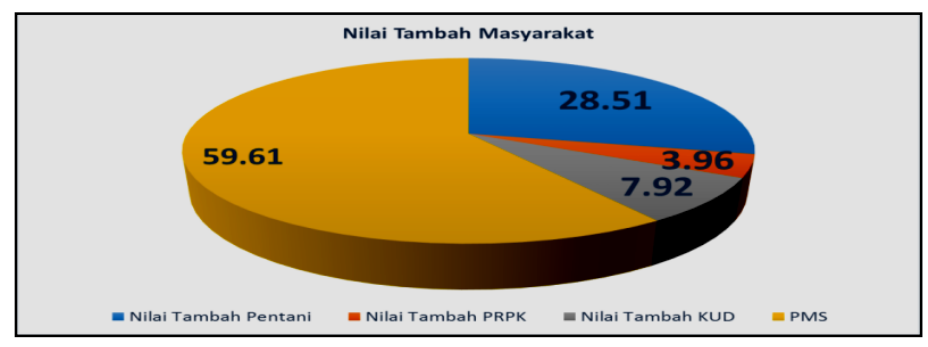

Source: Research Finding, 2014

Figure 3. The value-added distribution among the society

Based on the figure above, it is known that the largest value added distribution is obtained by PMS (59.61\%); while the farmers got 28.51 percent, cooperative obtained 7.92 percent, and PR-PK acquired 3.96 percent. The number of Gross Value Added (GVA) received by the farmers, PR-PK, KUD, and PMS is not the net to value, because it needs to be substracted by the activity costs. For farmers who received gross value added amounted to 28.51 percent, it needs to be substracted with the overall production cost during maintenance and production cost at 70 percent; thus, the Net to Value Added received is 8.553 percent ( $30 \%$ x 28.51). While PR-PK received Net to Value Added at 3.96 percent and KUD received 7.92 percent.

In such situation, it is unlikely for farmers to improve their welfare. Besides PMS, PR-PK and cooperatives are more likely to live prosperously. Therefore, a further study on the more efficient selling mechanism needs to be conducted so as the farmers can obtain a bigger net to value added as the party who contributed the most in production activity. It also needs to subsequently increase the farmers' income and welfare.

\subsection{Palm Oil Investment Model and Contract Farming and Their Influences on Farmers' Welfare}

Generally, the society in Meliau District perceives that the plantation pattern, pattern determination mechanism, and pattern implementation are quite satisfactory. However, some of them argue that the agreed stages are not preceded. Therefore, it has adversely impacted the farmers and further influences their income and welfare. This is mentioned by an informant (farmer) who stated that companies often do not have any ideas on palm oil price, yet they decide lower price than what has been agreed. He said "We are powerless and forced to sell the products based on the company's desire."

Observing from such condition, this reality is in accordance with Syaukat's (2010) statement that palm oil investment plays a major role in providing job opportunities both directly and indirectly. Besides, this research proves that what happens at the actual plantation is in line with Syahza's (2007) statement below:

The establishment of palm oil plantation causes double impacts to the regional economy, particularly in terms of creating job opportunities. As the platation grows, it has more impacts on the labors at the plantation and other sectors related to it. The impact can be seen from the farmers' income, as well as the increasing purchasing power of the villagers.

The ongoing palm oil plantation in Meliau District has not been able to provide a maximum advantage to the whole society, because it only focuses on the upstream industry and positions the area as a plantation area. Besides, there is also a problem related to the cooperation with the local farmers. These problems are not agreeable with some previous studies from Syahza (2007), Oladipo, (2008), and Korkeola (2011) who firmly assessed that palm oil plantation can absorb more labors, play a role as a driver of economy development and growth, and improve society's welfare and income. Multiparties agreement needs to be established within a framework which benefits each party. But, according to Agus and Adi (farmers), the existing cooperation agreement with the 8:2 division is unfair because it does not benefit the farmers. Nonetheless, the company still hold that division.

The contract farming occurring among PBN/PBS in Meliau District is supposed to be corresponding to the researches of Nagaraj (2008), Erfrit (2011), and Andrew (2009). They affirm that CF is a form of cooperation between farmers and corporations in which the terms and conditions on price, production, marketing, and commodities are contained; along with the input procurement, technology support, product quantity, and product quality. In this model (as seen in Figure 4), the relationship between farmers and corporations is not considered 
as seller-buyer, but corporations should function as the providers of input, technology, product quality, and product quantity.

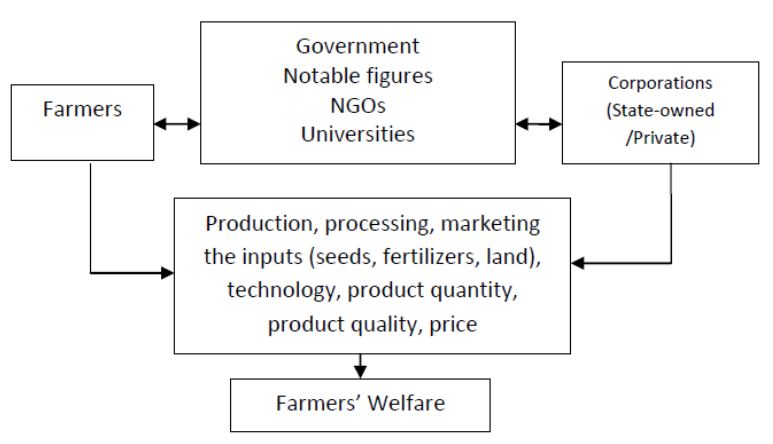

Figure 4. Contract farming development model

The appropriate contract farming system is supposed to be a cooperation mutually agreed by both farmers and corporations in all variables; starting from the production activity, processing, marketing the input (seeds, fertilizer, and land), technology, product quality and quantity, and price. Such cooperation is expected to strengthen the farmers' bargaining position and in turn, improve their welfare. To implement CF, supports from related parties, such as regional government, notable figures, NGOs, and universities, are required.

The production activity is influenced by the input factors, such as labors/farmers, natural resources, capital, technology, etc. The farmers need to be encouraged to preserve, maintain, and manage the palm oil optimally so that they can obtain fresh fruit bunches with $25 \mathrm{~kg}$ average weight. The fruit quality is a decisive factor for harvest and influences the production capacity of the palm oil so that the farmers can gain more income from the increasing harvest time. Furthermore, the increasing income will also enhance the farmers' purchasing power and in turn, enhance their welfare and society welfare.

\section{Conclusion and Suggestion}

1. Generally society in Meliau District perceives that cooperation agreement on palm oil farming between companies and farmers does not improve farmers' welfare.

2. The existing investment in Meliau District and West Kalimantan Province has only been focusing on upstream industry by limiting the area as plantation area. There has been no political will to accelerate the downstream industry to improve the farmers' income, encourage economy growth, and enhance the welfare quality in Meliau District, West Kalimantan Province.

3. Contract farming model is exceptionally prospective to be conducted through agreement, understanding, and common vision in terms of production, input management, technology, product quality and quantity and price, in order to be a win-win cooperation.

4. The role of provincial and regional government (as well as notable figures, NGOs, and universities) is necessary to support and monitor the contract farming system, in which the same bargaining position level between the farmers and the companies is expected.

\section{References}

Ahmadi, R. (2014). Metodelogi Penelitian Kualitatif, Cetakan 1. Ar-Ruzz Media, Yogyakarta.

Asokan,R. S., \& Singh, G.(2003). Role and Contraints of Contract Farming in Agro-Processing Industry. Indian Journal of Agricultural Economics, 58(3), 566-575.

Basrowi, S. (2008). Memahami Penelitian Kualitatif. Rineka Cipta, Jakarta

Basri, F. (2014). Revitalisasi Industri Manufaktur. Retrieved April17, 2014, from Kompas.com

Bijman, J. (2008). Contract Farming in Developing Countries: an overview. Wageningen Univesitiy Netherland.

BPS. (2013). Kalimantan Barat Dalam Angka. BPS Provinsi Kalimantan Barat., Pontianak.

BPS. (2014). Kalimantan Barat Dalam Angka. BPS Provinsi Kalimantan Barat, Pontianak.

Dinas Perkebunan Provinsi Kalimantan Barat. (2009). Statistik Perkebunan Kalimantan Barat.Pontianak. 
Djojohadikusumo, S. (1998). Perkembangan Pernikiran Ekonomi: Dasar Teori Ekonomi Pertumbuhan dan Ekonomi Pembangunan. LP3ES, Jakarta.

Erfit. (2011). Model Kemitraan Contract Farming Pada Agribisnis Holticultura (Contract Farming Partneship Model in Agribusiness). Jurnal Emberio, 4(1), 6-17.

Greve, B. (2008). What Is Welfare,Central European. Journal of Publik Policy, 2(1), 57-73. Roskidle University, Denmark.

Husodo, Y. S. (2007). Menuju Welfare State. Kumpulan Tulisan Tentang Kebangsaan, Ekonomi, dan Politik, Baris Baru, Jakarta.

Korkeola, O. (2011). Clearing The Land For What? Evaluating The Welfare Impact Of The Indonesian Palm Oil Production Expansion. University of Sussex United Kingdom, Inggris.

Kusreni, S., \& dan Sultan Sahab. (2009). Kebijakan APBN dan Kesejahteraan Masyarakat di Provinsi Sulawesi Selatan. DIE-Jurnal Ekonomi dan Manajemen, 5(3), 2-15.

Nagaraj, N., Chandrakanth, M. G., Chenggappa, P. G., Roop, H. S., \& Chandakavate, P. M. (2008). Contract Farming and its Implication for Input-Supply, Lingkages between Markets and Farmers in Karnataka. Agricultural Economics Research Review, 12, 307-316.

Oladipo. (2008). Agro Industry as Strategy for Rural development An Impact Assessment of Nigeria Oil-Palm Industry. European Journal of Socila Sciences, 7(1).

Prowse, M. (2012). Contract Farming in Developing Countries. Agence Francaisae Development.

Ruslan, R. (2006). Metode Penelitian. Jakarta: PT Raja Grafindo Persada.

Singh, S. (2000). Contract Farming for Agricultural Diversificatiob in the Indian Punjab: A Studi of Performance and Problem. Indian Journal of Agricultural Economics, 35(3), 241-261.

Sugiyono. (2011). Metode Penelitian Kombinasi (Mixed Methods), Cetakan Pertama, Alphabeta, Yogyakarta.

Suman, A. (2009). Ekonomika Politik dan Kesejahteraan. Pidato Pengukuhan Guru Besar. Retrieved February 20 , 2015,

from http://prasetya.ub.ac.id/berita/Prof-Dr-Agus-Suman-DEA-Ekonomika-Politik-dan-Kesejahteraan-3091

Susanne, V., \& Michael, K. (2014). Do Contract Farming and Property Righ Matter for Rural Development? Evidence from a Large-Scale Investment in Ghana. MAGKS, 16.

Syahza, A. (2007, October). Percepatan Pemberdayaan Ekonomi Masyarakat Pedesaan Dengan Model Agrostate Berbasis Kelapa Sawit. Jurnal Sorot, 2,106-118.

Syaukat, Y. (2010, June). Menciptakan Daya Saing Ekonomi dan Lingkungan IndustriKelapa Sawit Indonesia. Majalah Agribisnis, Manajemen dan Teknologi, 15(1).

Yani, M. (2010). Pengaruh Penanaman Modal dan Ekspor Perkebunan Terhadap Pertumbuhan Ekonomi Kalimantan Barat. Thesis, Program S2 Ilmu Ekonomi, Universitas Tanjungpura, Pontianak.

Yasin, M. (2011). Pembiayaan Usaha Tani dan Implikasinya Pada Pendapatan dan Kesejahteraan Petani Padi Dalam Persfektif Islam di Lombok Timur.Disertasi, Universitas Airlangga, Surabaya.

Zailani, A. R. (2013). Teknik Pengumpulan data Dalam Penelitian Kualitatif. Majalah IlmiahPawiyataan, XX(1), 82-92.

\section{Copyrights}

Copyright for this article is retained by the author(s), with first publication rights granted to the journal.

This is an open-access article distributed under the terms and conditions of the Creative Commons Attribution license (http://creativecommons.org/licenses/by/4.0/). 